\title{
Pentingnya Materi Lingkungan Dalam Pembelajaran Bahasa Indonesia Di Sekolah
}

\section{Ibnu Fajar Fatihan / 18016099}

\section{fajar199807@gmail.com}

Lingkungan diartikan sebagai segala benda, kondisi, keadaan dan pengaruh yang terdapat dalam ruangan yang kita tempat dan mempengaruhi hal yang hidup termasuk kehidupan manusia (Emil Salim 1976) Permasalahan mengenai lingkungan bukanlah suatu hal yang baru. Masalah lingkungan sangat erat kaitannya dengan pola hidup manusia begitu juga dengan perkembangan berbahasa manusia tersebut. Selain di negara kita Indonesia, permasalahan mengenai lingkungan juga dimiliki oleh negara lain. Masalah lingkungan ini terjadi akibat ulah manusia yang ceroboh terhadap alam guna memenuhi dan meningkatkan kualitas hidup mereka (Huang dan Kawata, serta Wihardjo dkk, dalam Ramadhan et al, 2019).

Salah satu yang menjadi penyebab utama dalam pencemaran lingkungan tidak hanya individu saja, tetapi juga sektor industri yang mengeluarkan limbah dari industri maupun polusi asap pabrik industri yang menyebabkan terpengaruhinya kondisi lingkungan, sumber daya alam, serta sumber daya manusia di sekitarnya. Lingkungan hidup yang sudah tercemar tersebut secara langsung akan mengancam kenyamanan dan meningkatkan kerentanan kehidupan setiap warga negara. Untuk itu pemerintah mestinya lebih tegas dalam menangani masalah lingkungan hidup dan lebih memperhatikan sektor-sektor industri yang menjadi salah satu penyebab adanya pencemaran lingkungan. Permasalahan lingkungan hidup semakin meningkat dan kompleks, berbagai program pengelolaan lingkungan hidup baik di tingkat pusat maupun tingkat daerah dirancang untuk mengatasi berbagai perkembangan permasalahan lingkungan hidup.

Kasus-kasus pencemaran lingkungan hidup ini karena kecerobohan atau kelalaian perusahaan-perusahaan industri termasuk industri tekstil membuang limbahnya secara sembarangan pada tempat-tempat seperti sungai yang masih digunakan oleh masyarakat, seperti untuk kebutuhan mandi, mencuci dan lainnya. Dan juga karena ketidakjujuran perusahaan-perusahaan industri membuang limbah yang tidak sesuai dengan ketentuan baku mutu atau batas maksimum limbah cair yang diperbolehkan dibuang ke lingkungan alam. Padahal dalam setiap kegiatan yang dilakukan oleh perusahaan, terutama dalam hal membuang limbah industri harus memiliki izin lingkungan. 
Kualitas lingkungan hidup yang semakin menurun telah mengancam kelangsungan perikehidupan manusia dan makhluk hidup lainnya sehingga perlu dilakukan perlindungan dan pengelolaan lingkungan hidup yang sungguh-sungguh dan konsisten oleh semua pemangku kepentingan. Masalah lingkungan hidup yang dihadapi masyarakat khususnya di kota besar sudah menjadi masalah yang dihadapi sehari-hari. Hal ini memberi kesan bahwa masyarakat sudah tidak peduli lagi terhadap masalah lingkungan tersebut. Ketidakpedulian ini disebabkan oleh berbagai sebab, salah satunya adalah kurangnya pendidikan. Oleh karena itu, perlu adanya pendidikan tentang lingkungan hidup yang diharapkan dapat meningkatkan kepedulian masyarakat pendidikan khususnya dan pada gilirannya masyarakat pada umumnya terhadap masalah lingkungan yang dihadapi, meningkatkan peran serta aktif masyarakat dalam menanggulangi masalah lingkungan hidup.

Untuk mengatasi ini, guru memainkan peran penting dalam mengajar pendidikan lingkungan dan menumbuhkan kesadaran siswa tentang lingkungan. Menurut Buldur dan Omeroglu (dalam Ramadhan et al, 2019), pendidikan lingkungan penting untuk meningkatkan sikap dan kesadaran siswa terhadap lingkungan. Untuk mengatasi permasalahan kerusakan lingkungan, diperlukan sebuah tindakan yang serius untuk mencegah kerusakan lingkungan yang semakin memburuk. Menurut Nazarenko dan Bergman (dalam Ramadhan et al, 2019).

Pembelajaran Pendidikan Lingkungan Hidup yang kini telah dan semakin semarak di terapkan di sekolah adalah bukan mempekerjakan siswa sebagai pekerja di lingkungan sekolah, tetapi membangun jiwa cinta lingkungan, dengan harapan bahwa generasi berikut menjadi generasi yang berbudaya lingkungan dan menjadi sebuah habit bagi semua civitas sekolah. Untuk maksud tersebut, maka hendaknya pihak sekolah dan semua stake-holder serta pemerhati lingkungan hidup melakukan konsitentisasi yang holistic kepada konsumen pendidikan tentang peran lingkungan terhadap keberlangsungan kehidupan di bumi, ancaman terhadap kehidupan dan solusi penyelamatan kehidupan di bumi, serta menjelaskan tentang porsi perhatian sekolah dalam hal ini siswa terhadap ekosistim lingkungan hidup sekitar.

Menurut Jacobs G M dan Cates K ( dalam Ramadhan et al, 2019), tujuan dari pendidikan lingkungan adalah untuk membuat siswa berpartisipasi dalam melindungi lingkungan adalah membuat siswa berpatisipasi dalam melindungi lingkungan. Peranan guru sangat diperlukan untuk mengajarkan pentingnya menjaga lingkungan hidup dan mengimplementasikan dalam kehidupan sehari-hari. Peran guru tidak hanya mengajarkan, akan tetapi juga sebagai motivator dalam pembelajaran lingkungan bagi siswa, agar siswa termotivasi untuk dapat 
menerapkan dalam kehidupan sehari-hari . Hal ini dapat dilakukan dengan memasukkan materi pentingnya lingkungan dalam pembelajaran bahasa Indonesia.

Dari data yang dihasilkan mengenai pembelajaran dan pengajaran bahasa sudah selayaknya berbasiskan lingkungan, 65\% menyatakan setuju 32,5\% menyatakan sangat setuju, dan 2,5\% menyatakan kurang setuju. Dalam pembelajaran bahasa yang bertemakan lingkungan merupakan salah satu indikasi untuk dapat membentuk kecerdasan hati, pikiran, dan tangan yang mana ketiga kopetensi tersebut mempunyai keterkaitan satu dengan yang lainnya, 55\% menyatakan setuju, $42,5 \%$ menyatakan sangat setuju, dan $2,5 \%$ menyatakan kurang setuju. Pembelajaran bahasa yang lebih "kontekstual" dengan alam harus kembali menjadi pilihan utama, 52,5\% menyatakan setuju, 30\% menyatakan sangat setuju, dan $17,5 \%$ menyatakan kurang setuju. Sebagai guru ataupun calon guru bahasa, sudah saatnya orientasi pembelajaran bahasa baik nasional maupun lokal harus menggunakan teks-teks yang bertemakan lingkungan, 57,5\% menyatakan setuju, 30\% menyatakan sangat setuju, dan $12,5 \%$ menyatakan kurang setuju. Pemanfaatan tema-tema pembelajaran tentang alam dalam pembagai seginya perlu dilakukan demi pengayaan bahan bacaan dan bahan pembelajaran bahasa, $67,5 \%$ responden menyatakan setuju dan 32,5\% responden menyatakan sangat setuju. Berpijak kuat di lingkungan alam sebagai ruang hidup pembelajaran bahasa sangat penting bagi para peserta didik, 62,5\% menyatakan setuju, $35 \%$ responden menyatakan sangat setuju, dan 2,5\% responden menyatakan kurang setuju. Lembaga pendidikan memiliki peran penting dalam proses penanaman pendidikan wawasan lingkungan kepada peserta didik, dan pendidik senantiasa menjadi penyambung proses nilai-nilai positif berbasis lingkungan kepada peserta didik, 50\% responden menyatakan setuju, $47,5 \%$ responden menyatakan sangat setuju, dan 2,5\% respondon menyatakan kurang setuju. Pendidikan wawasan lingkungan dapat diintegrasikan kedalam subyek mata pelajaran bahasa Indonesia untuk memberikan pengetahuan dan ketrampilan komprehensif dalam menjaga lingkungan, 72,5\% responden menyatakan setuju, 22,5\% responden menyatakan sangat setuju, dan 5\% responden menyatakan kurang setuju. Materi lingkungan memudahkan siswa dalam memamahami materi bahasa Indonesia dengan baik, menambah wawasan siswa,serta dapat membangun kecerdasan ekologis siswa, 62,5\% menyatakan setuju dan 37,5\% responden menyatakan sangat. Materi lingkungan merupakan materi yang sangat erat kaitannya dengan kehidupan sehari-hari, sehingga memudahkan guru mencari contoh yang relevan dan membuat siswa lebih paham akan materi yang diberikan, 50\% responden menyatakan setuju, 47,5\% responden menyatakan sangat setuju, $2,5 \%$ responden menyatakan kurang setuju. 
Dari hasil pengisian angket yang telah penulis lakukan dapat disimpulkan bahwa pada umumnya mahasiswa menyetujui bahkan sangat menyetujui adanya materi lingkungan dalam pembelajaran bahasa Indonesia. Karena dengan menggunakan tema lingkungan dalam pembelajaran bahasa Indonesia dapat memperkenalkan kepada siswa tentang lingkungan, sehingga diharapkan dapat meningkatkan rasa peduli siswa terhadap lingkungannya, khususnya terhadap kebersihan lingkungannya. 


\section{DAFTAR PUSTAKA}

Jacobs G M and Cates K.(2012). Global education in second language and teaching International Journal of Physical and Social Sciences 2 1-22

Kollmuss A and Agyeman J. (2002). Mind the gap: Why do people act enviconmentally and what are the barriers to pro-environmental behaviour Environmental Education Research 239-60

Lai C S. (2018) A study of fifth graders' environmental learning outcomes in Taip International Journal of Research in Education and Science 4 252-61

Mitsuki I. (2017) Beyond the limitations of environmental education in Japan Educational Studies in Japan: International Yearbook 3-14

Nieblas-Ortiz E C, Acrcos-Vega J L and Sevilla-Garcia J J 2017 The construction of an environmental management model based on sustainability indicators on a higher education institution in Mexico Higher Education Studies 7 15-22

Mitsuki, I. (2017). Beyond the limitations of environmental education in Japan Educational Studies in Japan: International Yearbook Number 11 pp 3-14

Bergman, B.G. (2016). Assessing impacts of locally designed environmental education projects on students' environmental attitudes, awareness, and intention to act Environmental Education Reseach 22(4) 480- 503

Buldur, A. and Ömeroglu, E. (2018). An examination of the relationship between pre-school children's and their teacher' attitute and awareness towards the environment Journal of Education and Learning 7(2) 221-9

Lai, C.S.(2018). A study of fifth graders' environmental learning outcomes in Taipei International Journal of Research in Education and Science 4(1) 252-61

Ramadhan, S., Sukma, E., \& Indriyani, V. (2019). Environmental education and disaster mitigation through language learning. IOP Conference Series: Earth and Environmental Science, 314.

Nazarenko, A.V. and Kolesnik, A.I. (2018). Raising environmental awareness of future teachers International Journal of Instruction 11(3) 63-76 